\title{
ABALON wt Allele
}

National Cancer Institute

\section{Source}

National Cancer Institute. ABALON wt Allele. NCI Thesaurus. Code C118116.

Human ABALON wild-type allele is located in the vicinity of $20 q 11.21$. This allele, which encodes apoptotic BCL2L1-antisense long non-coding RNA, is involved in the modulation of BCL2L1 protein expression. 